Journal of Bangladesh Academy of Sciences, Vol. 36, No. 1, 13-17, 2012

\title{
A SPINASTERYL GLYCOSIDE FROM IPOMOEA TURPETHUM L. HERB (STEM) GROWING IN BANGLADESH
}

\author{
MD. HARUN-OR-RASHID*, MD. ABDUL GAFUR, MD. MOKLESUR RAHMAN \\ SARKER $^{1}$ AND NURUL KARIM ${ }^{2}$
}

Department of Pharmacy, University of Rajshahi, Rajshahi-6205, Bangladesh

\begin{abstract}
Chromatographic purification and spectroscopic analysis of the constituents from the stem extract of Ipomoea turpethum L. reported 22, 23-dihydro- $\alpha$-spinasteryl- $\beta$-D glucoside $(\mathrm{H}-1)$ in addition to salicylic acid and $N$-p-comaryltyramine. The structures were elucidated by spectroscopic analysis including ${ }^{1} \mathrm{H}-\mathrm{NMR}$ and ${ }^{13} \mathrm{C}-\mathrm{NMR},{ }^{1} \mathrm{H}-{ }^{1} \mathrm{H}$ COSY, ${ }^{1} \mathrm{H}-{ }^{13} \mathrm{C}$ COSY, HMQC, HMBC, UV and IR spectroscopy. 22, 23-dihydro- $\alpha$-spinasteryl- $\beta$-D-glucoside is first reported from Ipomoea turpethum.
\end{abstract}

Key words : Ipomoea turpethum, 22, 23-dihydro- $\alpha$-spinasteryl- $\beta$-D-glucoside

\section{INTRODUCTION}

Ipomoea turpethum L. (Synonym- Operculina turpethum); Family- Convolvulaceae, is a large, perennial and climbing herb found in Southern, South east and the Barendra region of Bangladesh, India, Srilanka and other tropical regions of the World. It produces milky juice and reported to be effective against ascites, piles, snake bites, fever, ulcer, itching, bronchitis, muscle pain, constipation, anemia and jaundice in folk medicine (Kirtikar and Basu 1994). Previous phytochemical investigations revealed the presence of some triterpenoids (Sahabuddin 1999); $\beta$ sitosterol, betulin and lupeol (Nasar 1982); glycosidic resin, volatile oil (Kirtikar and Basu 1994, Wagner et al. 1978) and broad spectrum virus inhibitory activity (Khan 1992). Alcoholic extracts of the fresh fruits showed antibacterial activities against Micrococcus pyogens, var. aurus and E. coli (Welth of India 1966). Root and stem extracts have antioxidant and anti-cancer effect (Anbuselvum et al. 2007); and reported to be hepato-protective and anti-clastogenic effect (Ahmed et al. 2009). The present authors reported $\beta$-sitosteryl- $\beta$-D-glucoside (Daucosterol), salicylic acid and $N$-p-coumaryl tyramine from the stems of I. turpethum (Rashid et al. 2003); and evaluated the antibacterial, antifungal activity and cytotoxicity (Rashid et al. 2006). $N$-p-coumaryl tyramine showed significant antibacterial, antifungal activity and cytotoxicity. During the toxicological studies, it did not show any adverse

\footnotetext{
*Corresponding author: <mdhorashid@yahoo.com>.

${ }^{1}$ Department of Pharmacy, Daffodil International University, Dhaka-1207, Bangladesh.

2 Department of Biochemistry and Molecular Biology, Jahangirnagar University, Savar, Dhaka, Bangladesh.
} 
effect on Long evans rat (Rashid et al. 2004). So this plant may be a rich source of important metabolite of therapeutic and pharmacological interest and have the demand of research. Authors, herein, report the existence of another glycoside 22, 23-dihydro- $\alpha$ spinasteryl- $\beta$-D-glucoside (H-1) in I. turpethum.

\section{MATERIALS AND METHODS}

The stems of Ipomoea turpethum were collected from the rural areas of Rajshahi and Naogaon districts, Bangladesh during the winter season and were taxonomically identified. A voucher specimen has been maintained in the Department of Botany, Rajshahi University.

Melting point was recorded on a Gallenkamp melting point apparatus and UV spectra were recorded in $\mathrm{MeOH}$ on a Backman double beam spectrometer. IR spectra were obtained in $\mathrm{KBr}$ disc on a Perkin Elemer 1600 FTIR spectrometer. ${ }^{1} \mathrm{H}$ NMR (500 $\mathrm{MHz})$ and ${ }^{13} \mathrm{C}$ NMR (125 MHz) spectra were acquired on a JEOL JNM alpha spectrometer using TMS as an internal standard.

Air dried and pulverized stem $(300 \mathrm{~g} \times 3)$ was extracted by percolation (Rawshan 2002) in ethanol at $60^{\circ} \mathrm{C}$. The ethanol extract was successively partitioned with petroleum ether, chloroform and ethyl acetate. Evaporation of solvents provided 25, 2.8 and $1.5 \mathrm{gm}$ of petroleum ether, chloroform and ethyl acetate soluble materials, respectively. The chloroform solubles were fractionated by column chromatography (CC) over silica gel (Merck, mesh 60-120) using n-hexane-chloroform mixture of increasing polarities. Cent per cent chloroform afforded compound $2(12 \mathrm{mg})$ and $\mathrm{H}-1$ (10 $\mathrm{mg})$ which were purified by repeated TLC and PTLC using Merck silica gel $60\left(\mathrm{GF}_{254}\right)$ on glass plates at a thickness of $0.5 \mathrm{~mm}$ at the multiple development of chloroformmethanol, $7: 1\left(\mathrm{R}_{\mathrm{f}}\right.$ value 0.25$)$ and $4: 1\left(\mathrm{R}_{\mathrm{f}}\right.$ value 0.35$)$, respectively. The spots on TLC and PTLC were visualized under UV light (254 and $260 \mathrm{~nm}$ ) and spraying with $1 \%$ vanillin sulphate followed by heating at $110^{\circ} \mathrm{C}$ for 5 minutes. Antibacterial, antifungal and cytotoxicity studies were done according to reported method (Rashid et al. 2006).

Ash white crystalline powder $(\mathrm{MeOH}), \mathrm{mp} 284-286^{\circ} \mathrm{C}$ \{spinasteryl-glucoside, lit. $279-283^{\circ} \mathrm{C}$ (Ariswa et al. 1985)\}; UV (MeOH) $\lambda_{\max }: 205.2 \mathrm{~nm}$; IR (KBr) $v_{\max }$ : 1091, 1374, 1472, 2897, 3403/cm; ${ }^{1} \mathrm{H}-\mathrm{NMR}\left(500 \mathrm{MHz}, \mathrm{C}_{5} \mathrm{D}_{5} \mathrm{~N}\right) \delta: 0.60(3 \mathrm{H}, \mathrm{s}, \mathrm{H}-18), 0.74$ (3H, s, H-19), 0.88 (3H, d, $J=6.42 \mathrm{~Hz}, \mathrm{H}-27), 0.91$ (3H, t, $J=6.5 \mathrm{~Hz}, \mathrm{H}-29), 0.92$ (3H, d, $J=6.42 \mathrm{~Hz}, \mathrm{H}-26), 0.94$ (1H, t H-9), 1.02 (3H, d, $J=7.0 \mathrm{~Hz}, \mathrm{H}-21), 1.08$ (1H, m, H24), 1.09 (2H, d, $J=13.07 \mathrm{~Hz}, \mathrm{H}-11), 1.10$ (2H, m, H-23), 1.13 (2H, m, H-4), 1.15 (1H, t H-14), 1.16 (1H, d, $J=13.20 \mathrm{~Hz}, \mathrm{H}-17), 1.27$ (2H, m, H-16), 1.29 (2H, m, H-15), 1.31 (2H, m, H-28), 1.40 (2H, m, H-22), 1.72 (2H, m, H-1), 1.73 (1H, m, H-25), 1.75 (2H, m, H-6), 1.85 (2H, m, H-12), 1.94 (1H, bd, $J=11.3 \mathrm{~Hz}, \mathrm{H}-5), 1.96$ (1H, m, H-20), 2.50 (1H, $\mathrm{t}, J=11.76 \mathrm{~Hz}, \mathrm{H}-2), 2.75(1 \mathrm{H}, \mathrm{dd}, J=2.0,2.5 \mathrm{~Hz}, \mathrm{H}-2), 3.96(1 \mathrm{H}, \mathrm{m}, \mathrm{H}-3), 4.0(1 \mathrm{H}, \mathrm{m}$, 
$\left.\mathrm{H}-5^{\prime}\right), 4.09\left(1 \mathrm{H}, \mathrm{t}, J=8.3 \mathrm{~Hz}, \mathrm{H}-2^{\prime}\right), 4.31\left(1 \mathrm{H}, \mathrm{t}, J=8.07 \mathrm{~Hz}, \mathrm{H}-3^{\prime}\right), 4.32(1 \mathrm{H}, \mathrm{t}, J=8.07$ $\left.\mathrm{Hz}, \mathrm{H}-4^{\prime}\right), 4.45\left(1 \mathrm{H}, \mathrm{dd}, J=5.0,11.67 \mathrm{~Hz}, \mathrm{H}-6^{\prime}\right), 4.59\left(1 \mathrm{H}, \mathrm{dd}, J=2.50,11.25 \mathrm{~Hz}, \mathrm{H}-6^{\prime}\right)$, $5.07\left(1 \mathrm{H}, \mathrm{d}, J=8.2 \mathrm{~Hz}, \mathrm{H}-1^{\prime}\right), 5.36(1 \mathrm{H}, \mathrm{bs}, \mathrm{H}-7) ;{ }^{13} \mathrm{C}-\mathrm{NMR}\left(125 \mathrm{MHz}, \mathrm{C}_{5} \mathrm{D}_{5} \mathrm{~N}\right) \delta: 12.0$ (C-18), 12.2 (C-19), 19.0 (C-21), 19.2 (C-27), 19.4 (C-29), 20.0 (C-26), 21.3 (C-11), 23.4 (C-15), 24.5 (C-23), 26.4 (C-28), 28.6 (C-16), 29.5 (C-25), 30.3 (C-2), 30.3 (C-6), 32.1 (C-20), 34.2 (C-22), 36.4 (C-10), 37.0 (C-4), 37.5 (C-1), 39.4 (C-12), 40.0 (C-5), 42.5 (C-13), 46.1 (C-24), 50.4 (C-9), 56.3 (C-17), 56.9 (C-14), 78.1 (C-3), 121.9 (C-7), 140.9 $(\mathrm{C}-8), 102.6\left(\mathrm{C}-1^{\prime}\right), 75.4\left(\mathrm{C}-2^{\prime}\right), 78.5\left(\mathrm{C}-3^{\prime}\right), 71.7\left(\mathrm{C}-4^{\prime}\right), 78.6\left(\mathrm{C}-5^{\prime}\right), 62.9\left(\mathrm{C}-6^{\prime}\right)$.

\section{RESULTS AND DISCUSSION}

A combination of $\mathrm{CC}$ and repeated PTLC afforded compound $\mathrm{H}-1$ and 2 from chloroform solubles and compound 3 from ethyl acetate solubles. Identification and characterization of compound 2 (Salicylic acid) and 3 ( $N$-p-comaryl-tyramine) were reported in authors' previous report (Rashid et al. 2003). H-1 appeared as dark spot under UV light and developed bright pink to gray coloration when sprayed with $1 \%$ vanillinsulphate followed by heating which indicates the presence of glycoside. UV spectrum $\lambda_{\max }$ at $205.2 \mathrm{~nm}$ may be due to single unsaturation. ${ }^{1} \mathrm{H}-\mathrm{NMR}$ data exhibited two tertiary methyl proton peaks at $\delta 0.60(\mathrm{~s}, \mathrm{H}-18), 0.74(\mathrm{~s}, \mathrm{H}-19)$; three secondary methyl proton peaks at $\delta 1.02$ (d, $J=7.0 \mathrm{~Hz}, \mathrm{H}-21), 0.92$ (d, $J=6.42 \mathrm{~Hz}, \mathrm{H}-26), 0.88$ (d, $J=6.42 \mathrm{~Hz}$, $\mathrm{H}-27$ ); one primary methyl proton peak at $\delta 0.91(\mathrm{t}, J=6.5 \mathrm{~Hz}, \mathrm{H}-29)$; one anomeric proton peak at $\delta 5.07\left(\mathrm{~d}, J=8.2 \mathrm{~Hz}, \mathrm{H}-1^{\prime}\right)$; one olefinic proton peak at $\delta 5.36(\mathrm{bs}, \mathrm{H}-7)$; one oxygen substituted methine proton peak at $\delta 3.96(\mathrm{~m}, \mathrm{H}-3)$. These proton data suggested that compound H-1 is a steroidal glycoside (Gafur et al. 1997, Kojima et al. 1990). In ${ }^{13} \mathrm{C}-\mathrm{NMR}$ spectrum six carbon peaks at $\delta 102.6\left(\mathrm{C}-1^{\prime}\right), 75.4\left(\mathrm{C}-2^{\prime}\right), 78.5\left(\mathrm{C}-3^{\prime}\right)$, $71.7\left(\mathrm{C}-4^{\prime}\right), 78.6\left(\mathrm{C}^{\prime} 5^{\prime}\right)$ and $62.9\left(\mathrm{C}^{-} 6^{\prime}\right)$ are similar to those of methyl $\beta$-D-glucose, which indicates the presence of a $\beta$-D-glucose unit (Zhao et al. 1992). In IR spectrum $v_{\max }$ $3403 / \mathrm{cm}$ for $\mathrm{O}-\mathrm{H}$ stretching (In $\beta$-D-glucose unit); $2897 / \mathrm{cm}$ for $\mathrm{C}-\mathrm{H}$ stretching and $1374 / \mathrm{cm}$ and $1472 / \mathrm{cm}$ for $-\mathrm{C}=\mathrm{C}$ - stretching present as the olefinic carbon. In ${ }^{1} \mathrm{H}^{13}{ }^{13} \mathrm{C}$ COSY the olefinic proton $5.36(1 \mathrm{H}, \mathrm{bs}, \mathrm{H}-7)$ is related to olefinic carbon peak $121.9(\mathrm{C}-$ 7). In HMBC it showed that another olefinic tertiary carbon 140.9 (C-8) is correlated to proton peak $0.94(1 \mathrm{H}, \mathrm{t} \mathrm{H}-9)$ and $1.15(1 \mathrm{H}, \mathrm{t} \mathrm{H}-14)$. In ${ }^{13} \mathrm{C}-\mathrm{NMR}$ spectrum 29 carbon peaks are similar to those of 22, 23-dihydro- $\alpha$-spinasterol (Kojima et al. 1990, Ling et al. 2010), except C-3 (78.1 ppm instead of 71.7 ppm). The carbon peak at $\delta 78.1$ (C-3) was shifted down field by $6.4 \mathrm{ppm}$, which indicates that the glycone part ( $\beta$-D-glucose unit) is attached at C-3 which showed $v_{\max } 1091 / \mathrm{cm}$ for C-O stretching in IR spectrum. 22, 23 dihydro derivative is confirmed by the presence of two methine proton peak at $\delta 1.40$ $(2 \mathrm{H}, \mathrm{m}, \mathrm{H}-22)$ and $1.10(2 \mathrm{H}, \mathrm{m}, \mathrm{H}-23)$ instead of two olefinic proton peak at 5.07, 5.21 (each $1 \mathrm{H}, \mathrm{dd}, J=15.1,9.0 \mathrm{~Hz}, \mathrm{H}-22,23$ ) in alpha-spinasteryl- $\beta$-D-glucoside (Kojima et 
al. 1990, Gafur et al. 1997). Hence H-1 is characterized and identified as the 22, 23dihydro- $\alpha$-spinasteryl- $\beta$-D-glucoside.

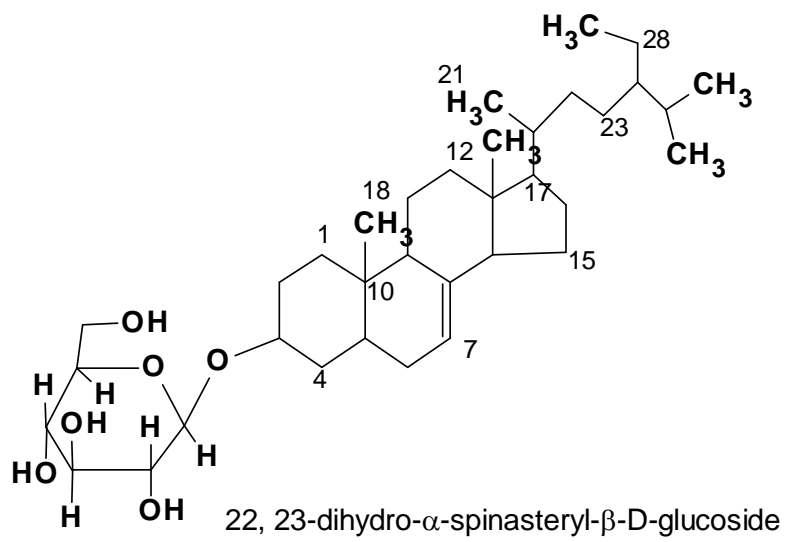

$\alpha$-spinasterol, 22, 23-dihydro- $\alpha$-spinasterol (Janson et al. 2009, Elvia et al. 2010, Jeong et al. 2004, Ling et al. 2010), and $\alpha$-spinasteryl- $\beta$-D-glucoside (Kojima et al. 1990, Gafur et al. 1997) were reported from various plant sources. But 22, 23-dihydro- $\alpha$ spinasteryl- $\beta$-D-glucoside was not reported earlier. Structurally related compound $\beta$ sitosterol have been reported from I. turpethum (Nasar 1982). Therefore, isolation of 22 , 23 -dihydro- $\alpha$-spinasteryl- $\beta$-D-glucoside supports its placement in I. turpethum.

The antibacterial, antifungal and cytotoxicity studies of $\mathrm{H}-1$ did not show any significant activity (data not shown). But $\alpha$-spinasterol was reported to be a potent inhibitor of glomerular mesengial cell proliferation caused by high ambient glucose and control the streptozocin induced diabetic nephropathy in mice (Jeong et al. 2004) and have the antioxidant property (Elvia et al. 2010). But it is yet to be known that its dihydro-glycoside possesses such kinds of activity or not, may be interesting for further research.

\section{ACKNOWLEDGEMENTS}

Authors wish to thank National Instiute of Health Science, Tokyo, Japan to provide the facilities of NMR analysis and to the authority of Beximco Pharma Ltd., Bangladesh, for UV and IR spectral analysis. They also thank to Professor ATM Naderuzzaman, Department of Botany, University of Rajshahi, Bangladesh, for his help in identifying the plant. 


\section{REFERENCES}

Ahmed, R., S. Ahmed, N. U. Khan and A. Hasnain. 2009. Operculina turpethum attenuates $N$ nitrosodimethylamine induced toxic liver injury and clastogenicity in rats. Chemico-Biol. Interactions 181(2): 145-153.

Anbuselvam, C., K. Vijayavel and M. P. Balasubramanian. 2007. Protective effect of Operculina turpethum against 7, 12-dimethyl benz(a)anthracene induced oxidative stress with reference to breast cancer in experimental rats. Chemico-Biol. Interactions 168(3): 229-236.

Ariswa, M., M. Yoshizaki and N. Morita. 1985. Shoyakugaku Zasshi. 39: 316-319.

Elvia, C. U., P. C. Jose and E. A. J. Javier. 2010. Antioxident activity of Heterotheca inuloides extrats and some of its metabolitos. Toxicolog. 276 (1): 41-48.

Gafur, M. A., T. Obata, F. Kiuchi and Y. Tsuda. 1997. Acacia concinna saponins. I structures of prosapogenols, concinnosides A-F, Isolation from the alkaline hydrolysate of the highly polar saponin fraction. Chem. Pharm. Bull. 45: 620-625.

Janson, E. M., R. J. Grebenok and A. Patrick. 2009. Same host-plant, different sterols: variation in sterol metabolism in an insect herbivore community. J. Chem. Ecol. 35(11): 1309-1319.

Jeong, S. I., K. J. Kim, M. K. Choi, K. S. Keum, S. Lee, S. H. Ahn, S. H. Back, J. H. Song, Y. S. Ju, B. K. Choi and K.Y. Jung. 2004. Alpha-spinanasterol isolated from the root of Phytolacca americana and its pharmacological property on diabetic nephropathy. Planta Med. 70: 736-739.

Khan, M. A. 1992. Physicochemical properties and mode of action of inhibitors of plant virus replication present in Ipomoea turpethum and Scilla indica. Z. Pflanzenkrankh. Pflanzenschutz. 99:71-73.

Kirtikar, K. R. and B. D. Basu. 1994. Indian Medicinal Plants. Dehradun, India 3: 170.

Kojima, H., N. Sato, A. Hantano and H. Ogura. 1990. Sterol glucosides from Prunilla vulgaris. Phytochemistry 29: 2351-2355.

Ling, T. J., X. C. Wan, W. W. Ling, Z. Z. Zhang, T. Xia, D. X. Li and R. Y. Hou. 2010. New triterpenoids and other constituents from a special microbial-fermented tea-Fuzhuan brick tea. J. Agric. Food Chem. 58: 4945-4950.

Nasar, E. L. S. M. M. 1982. Coumarins of Convolvulus lantus and C. arvensis. Fitoterapia 53: 189-191.

Rashid, M. H. O., M. A. A. Rahman, M. A. Gafur, M. G. Sadik, A. H. M. K. Alam, N. Sugimoto, R. Chowdhury and M. A. Rashid. 2003. Chemical constituents of Ipomoea turpethum. Dhaka Univ. J. Pharm. Sci. 2: 73-76.

Rashid, M. H. O., M. A. A. Rahman, M. G. Sadik, M. A. Habib and M. A. Gafur. 2004. Toxicological studies of a novel acrylamide isolated from Ipomoea turpethum. Bangladesh J. Physiol. Pharmacol. 20(1/2): 16-18.

Rashid, M. H. O., N. Karim M. A. Gafur, M. G. Sadik, A. S. M. Anisuzzaman, N. Sugimoto and A. T. M. Z. Azam. 2006. Isolation and biological activities of chemical constituents from the stems of Ipomoea turpethum. Pak. J. Biol. Sciences 9: 2261-2266.

Rashwan, O. A. 2002. New phenylpropanoid glucosides from Eucalyptus amculata. Molecules 7: 75-80.

Sahabuddin, M. 1999. Triterpenoids from the stems of Operculina turpethum L. (Convolvulaceae). Dhaka University J. Biol. Sci. 8: 157-163.

Wagner, H., G. Wenzel and V. M. Chari. 1978. Chemical constituents of the Convolvulaceae resins III. The turpenthinic acids of I. turpethum L. Planta Med. 33: 144-151.

Zhao, G., Y Hui, J. K. Rupprecht, J. L. Melaughlin and K. V. Wood. 1992. Additional bioactive compounds and trilobactin, a novel highly cytotoxic acetogenin, from the bark of Asimina triloba. J. Nat. Prod. 55: 347-356. 